\title{
Weeds as Reservoirs of Plant Pathogens Affecting Economically Important Crops ${ }^{1}$
}

\author{
Morgan Byron, Danielle Treadwell, and Peter Dittmar ${ }^{2}$
}

\section{Introduction}

Weeds are a major contributor to yield loss and reduction in yield quality in an agricultural setting, competing with the crop for resources like light, water, and nutrients. This competition, along with the cost of weed management strategies like tillage and herbicides, is responsible for the economic impact of weeds, which can reach into the billions (Dille et al. $2016 \mathrm{a}, \mathrm{b}$ ). In addition to the damage caused by direct competition, weeds can also harm crop plants by acting as reservoirs for destructive plant pathogens, the insect vectors that move these pathogens from plant to plant, or both. The objective of this publication is to summarize previously published weed-pathogen associations to help growers scout and monitor pathogens in weeds near production areas.

Plant pathogens-primarily fungi, bacteria, and viruses-are organisms that interfere with a plant's regular metabolism and function, causing disease symptoms. Different types of pathogens require various methods of control, prevention, and diagnosis. In almost all cases, removal of the source of the pathogen is an important means of reducing damage to the crop. If weedy plant species within the field itself or in nearby unmanaged land are capable of harboring pathogens that can affect the crop, identification and removal of these weeds would reduce the risk of economic loss.
Identifying weed species that can harbor plant pathogens can be challenging due to a number of key factors.

Populations of weeds are typically more genetically diverse compared to a crop species and thus demonstrate patchy susceptibility to certain pathogens. Another challenge is that weeds are usually not evenly distributed across a geographic location, like a crop planted in rows, and therefore may be difficult to observe and quantify. Additionally, weedy areas must be scouted year-round because weed populations in a given area tend to undergo successional shifts in populations, making a predictive model difficult to design.

Identifying weed species that can act as potential pathogen reservoirs can influence the pest management plan for a given growing season, allowing the grower to prioritize and plan accordingly. It may be worth the extra time and effort to scout for weeds in areas adjacent to a field that are otherwise ignored. The prevalence of certain weeds and potential pathogens may even inform cultural IPM decisions, like the timing of planting, crop cultivar or variety, or crop rotation schedule.

\section{Types of Pathogens and Symptoms}

Understanding the broader types of plant pathogens can be important for scouting and monitoring the crop and surrounding wild areas. Different pathogen types have

1. This document is HS1335, one of a series of the Horticultural Sciences Department, UF/IFAS Extension. Original publication date September 2019. Visit the EDIS website at https://edis.ifas.ufl.edu for the currently supported version of this publication.

2. Morgan Byron, Doctor of Plant Medicine Program graduate; Danielle Treadwell, associate professor; and Peter Dittmar, associate professor, Horticultural Sciences Department; UF/IFAS Extension, Gainesville, FL 32611.

The Institute of Food and Agricultural Sciences (IFAS) is an Equal Opportunity Institution authorized to provide research, educational information and other services

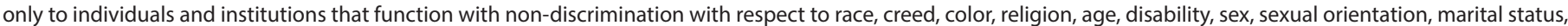

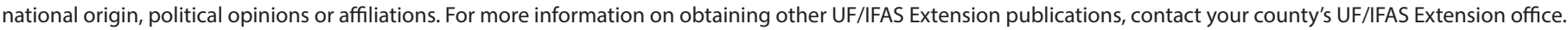
U.S. Department of Agriculture, UF/IFAS Extension Service, University of Florida, IFAS, Florida A \& M University Cooperative Extension Program, and Boards of County Commissioners Cooperating. Nick T. Place, dean for UF/IFAS Extension. 
different signs, or physical indications, that they have infected a plant.

Fungal pathogens are comprised of hyphae, filamentous strands that make up the body of the fungus itself. Fungi are able to penetrate their host plants via modified hyphae that can break through the plant's cuticle or enter via wounds or stomates of the leaves. Once the fungus enters the host plant tissue, it accesses the plant's vascular system, removing nutrients and carbohydrates. This can weaken the plant and produce a variety of symptoms, like leaf spots or fruit rot. Signs of fungal infection include mycelia (masses of hyphae) and various fungal fruiting bodies or overwintering structures that release spores.

Bacterial pathogens cannot enter the plant without a preexisting wound or opening. Plants can be wounded easily, either mechanically via pruning, through insect feeding, or through accidental injury due to weather or machinery. Bacterial pathogens thrive in humid environments and move through water on and around the host plant. Reducing moisture in the microenvironment surrounding plants can help reduce the incidence and spread of bacterial pathogens in the field. Typical symptoms of bacterial diseases are wilting, blighting, and damping off of young plants. Signs of bacterial infection are not commonly seen in the field but may present as whitish opaque ooze coming from the plant.

Viral pathogens enter and infect the plant either through mechanical movement of infected plant sap-such as through pruning an infected plant and using the same tool to prune an uninfected plant-or through insect vector feeding. One of the most effective ways to reduce the incidence of viral disease in the field is to be aware of infected plants and remove them immediately. Sanitation of tools used on various plants can also be important if the virus can be spread mechanically. Viral symptoms are typically unusual patterning of the leaves, as in a mottle or mosaic, or changes to plant architecture and growth. Signs of the virus will never be seen in the field, because these pathogens are microscopically small.

\section{Plant Families of Interest}

Not all plant pathogens are host-specific; in fact, many can infect a wide variety of plants over many plant families. However, weeds that are found in the same family as the crop being cultivated can share many botanical similarities that make them susceptible to the same pathogens. Virtually all cultivated plants have wild ancestors that occur naturally in the environment, along with the insect pests and various pathogens that affect them. With this in mind, the following is a description of plant families that contain common crops and weeds, along with examples of pathogens that can utilize these weed populations as a reservoir of inoculum. Table 1 presents these relationships in brief. Figures 1 through 6 illustrate examples of species in the families presented below.

\section{Amaranthaceae}

The amaranth family, Amaranthaceae, contains some important crop species, like spinach, beets, and quinoa, as well as pigweeds (Amaranthus spp.), a group of some of the most difficult-to-eradicate weeds. Palmer amaranth, Amaranthus palmeri, is a particularly aggressive and hardto-control weed in Florida. Palmer amaranth along with lambsquarters (Chenopodium album) have been demonstrated to act as reservoirs of Tobacco rattle virus, which can cause chlorotic mottling or yellow streaks on sugar beet, tobacco, and potato (Dikova 2006, Goyal et al. 2012).

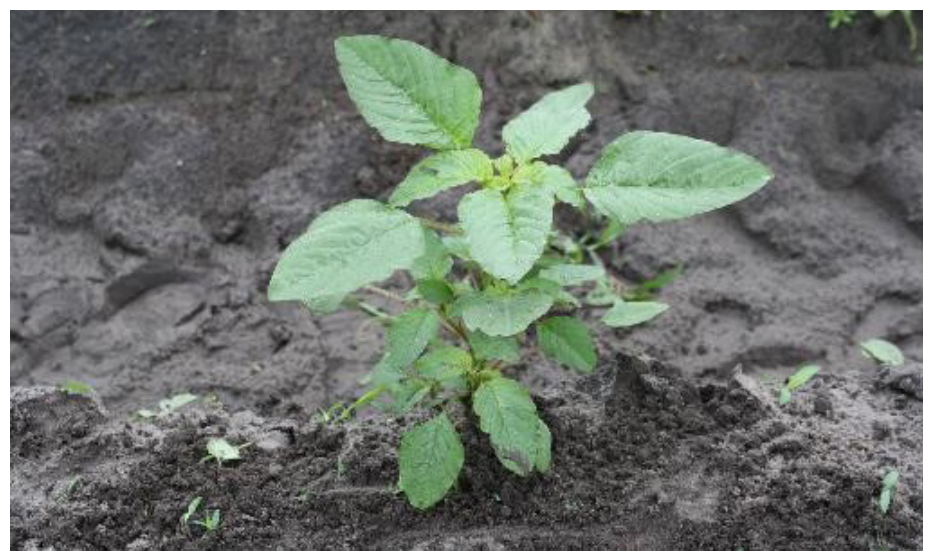

Figure 1. Palmer amaranth, a member of the Amaranthaceae family. Credits: P. Dittmar, UF/IFAS

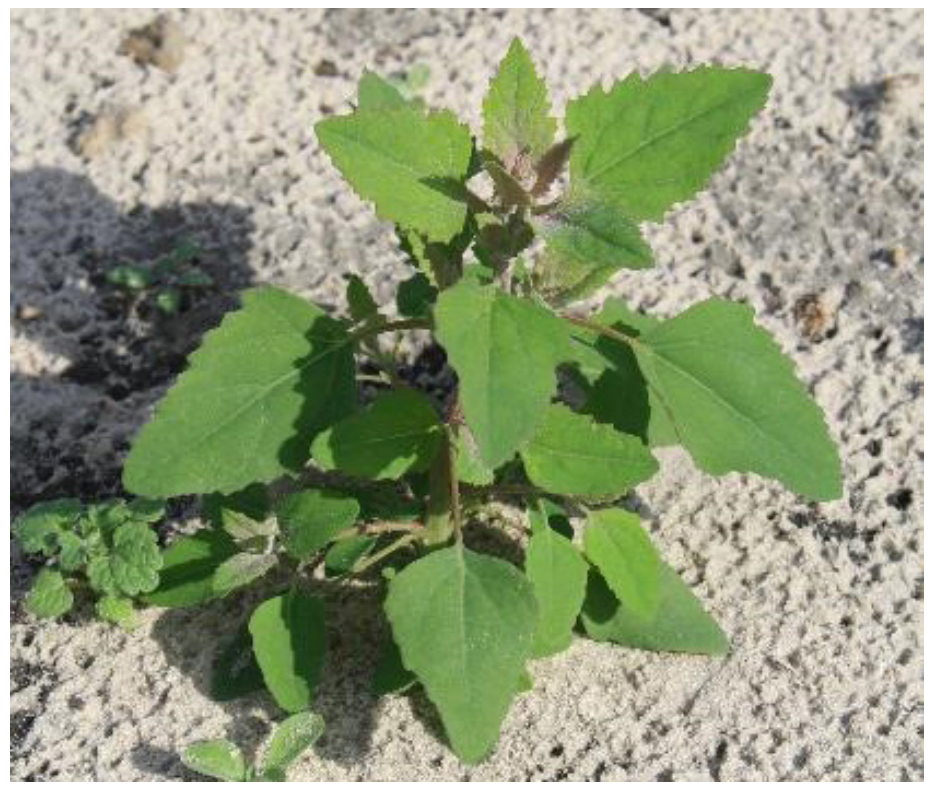

Figure 2. Common lambsquarters, a member of the Amaranthaceae family.

Credits: P. Dittmar, UF/IFAS 


\section{Brassicaceae}

Crops in the Brassicacae family are collectively known as crucifers or mustards and include broccoli, cabbage, radish, and other important vegetable crops. Wild radish, Raphanus raphanistrum, is a common weed found in disturbed areas like abandoned fields and along roadways. It has been demonstrated to be a host of Beet western yellows virus, which can cause yellowing, stunting, and leaf abnormalities in many leguminous crops, as well as canola (also known as rapeseed), a brassicaceous seed crop, and lettuce (Aftab and Freeman 2013, Zitter and Provvidenti 1984).

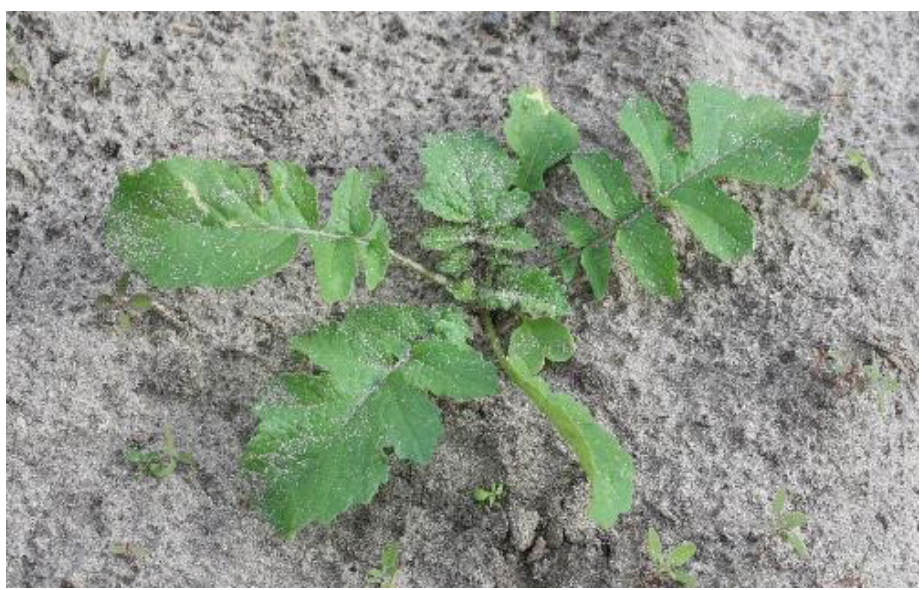

Figure 3. Wild radish, a member of the Brassicaceae family. Credits: P. Dittmar, UF/IFAS

\section{Cucurbitaceae}

Crops in the Cucurbitaceae family, called cucurbits, include cucumbers, squash, and melons. Many weeds in this family are the wild ancestors of the familiar plants cultivated for food and are susceptible to many of the same insect pests and pathogens. Wild cucurbits (Cucumis spp.) can act as reservoirs of Cucumber mosaic virus, which affects cantaloupe, cucumber, pumpkin, and squash, in addition to many noncucurbit crops like bell pepper, celery, spinach, tomato, and watercress (Goyal et al. 2012). This virus causes stunting of infected plants and can cause a roughness to develop on the skin of the fruit, making it unmarketable (Zitter and Murphy 2009). Creeping cucumber (Melothria pendula), another weed that is found throughout most of Florida, is a reservoir for a number of viruses that affect cucurbit crops, including Papaya ringspot virus type W, which is vectored by aphids, and Zucchini yellow mosaic virus (Goyal et al. 2012).

Momordica charantia, known commonly as balsam apple or balsam pear, is a wild cucurbit weedy species that can act as a reservoir of pathogens like Squash vein yellowing virus, a whitefly-transmitted virus that causes watermelon vine decline, a serious disease of squash and watermelon (Baker et al. 2008, Shrestha et al. 2016). This virus is transferred from infected hosts to healthy plants via the whitefly, Bemisia tabaci (Baker et al. 2008). Viruses spread by insect vectors are especially important to monitor for in the field and surrounding weedy areas because these insects are often very efficient in moving the virus relatively long distances in a short period of time.

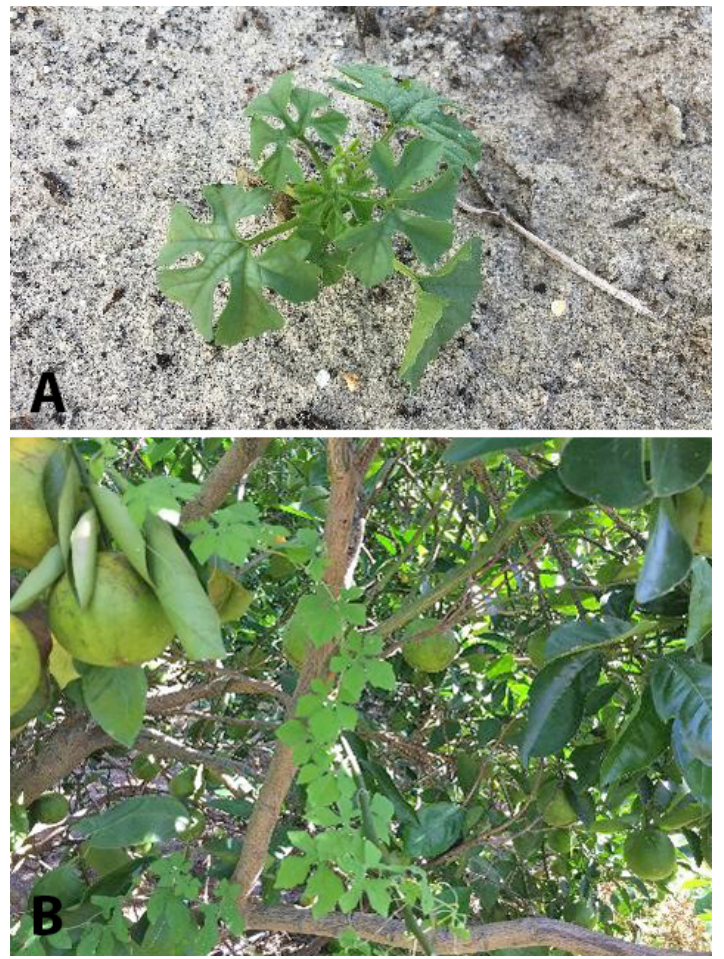

Figure 4. Balsam apple vine, a member of the Cucurbitaceae family, a) as a young plant, and $b$ ) as a mature vine.

Credits: P. Dittmar, UF/IFAS

\section{Fabaceae}

The legumes, members of the Fabaceae family, are an important group for crops and weeds. All beans and peas reside in this family, as do a number of important weeds. Kudzu (Pueraria montana var. lobata) is a notoriously noxious weed known for its rapid growth rate and ability to smother native vegetation. In addition to causing problems along roads and in natural areas due to its weedy growth habit, kudzu can act as a host of soybean rust (Phakopsora pachyrhizi and P. meibomiae), a fungal disease that can be devastating to many leguminous crops (Rupe and Sconyers 2008). Both species of this rust fungus cause reddish leaf spots as an early symptom, maturing into lesions with spores that can spread via wind to new plants. As the disease progresses, the lesions grow in number and size, which can cause defoliation of infected plants. Other weeds in this family may act as reservoirs of soybean rust as well, including species of clover (Trifolium spp.) and Florida beggarweed (Desmodium tortuosum) (Rupe and Sconyers 2008). 


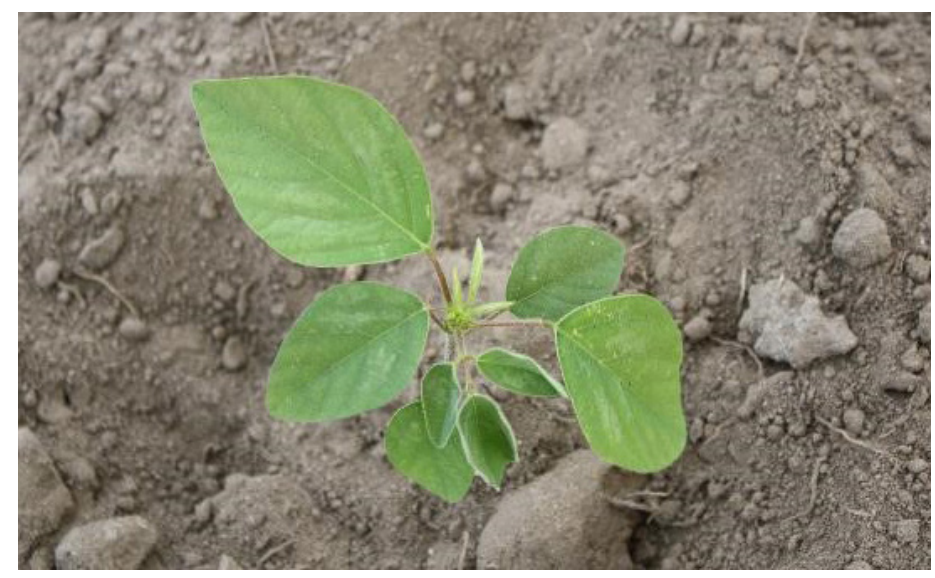

Figure 5. Florida beggarweed, a member of the Fabaceae family. Credits: P. Dittmar, UF/IFAS

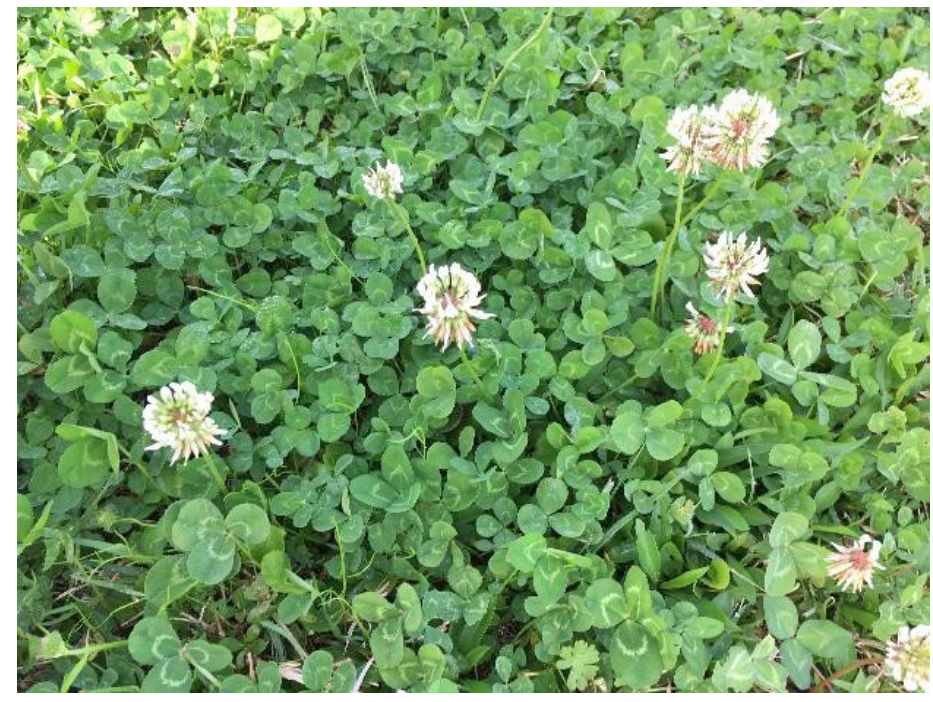

Figure 6. White clover, a member of the Fabaceae family. Credits: P. Dittmar, UF/IFAS

\section{Poaceae}

Poaceae, the grass family, includes many of the most common and difficult-to-manage weeds. It is also the plant family to which corn, sugarcane, sorghum, and wheat belong. Crops in this family are vulnerable to infection by a number of viral pathogens. Sweet corn in the Southeast, for example, can be affected by several plant viruses. Maize dwarf mosaic virus A can be spread mechanically, through infected seeds, or through the feeding of insect vectors, like aphids. These modes of transmission are exacerbated by the ability of Johnsongrass (Sorghum halapense), a common weedy grass, to act as a reservoir for this virus (Gatton 2015). Therefore, it is important to scout for Johnsongrass growing near corn fields, especially noting any symptoms of Maize dwarf mosaic virus A infection, like chlorotic (yellow) blotches or streaks along the leaves.

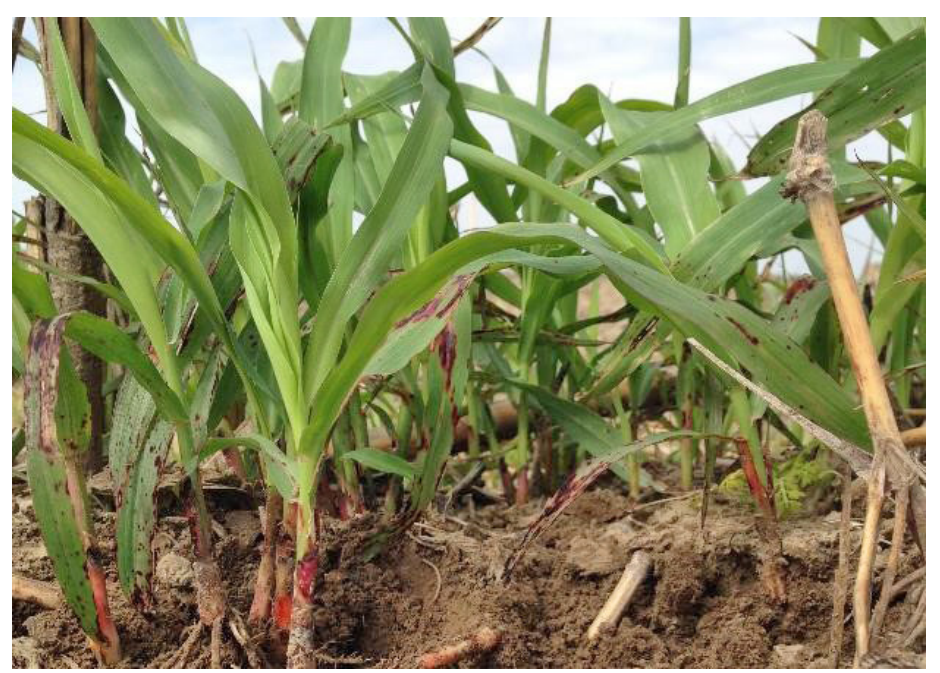

Figure 7. Johnsongrass, a member of the Poaceae family. Credits: A. Orgeron, LSU

\section{Solanaceae}

This family is often referred to as the nightshade family and contains many common vegetable and field crops, such as tomato, pepper, and tobacco. It also contains some important weed species, such as groundcherry (Physalis sp.) and Jimsonweed (Datura stramonium). Several viruses that affect pepper and tomato, including Tomato mosaic virus and Potato virus $X$, can infect Jimsonweed and cause it to act as a reservoir (Alemu et al. 2002). Tomato mosaic virus infection produces various symptoms in solanaceous crops, mainly abnormal, chlorotic patterns on young leaves and overall stunting of the plants. Potato virus $X$ infection results in a mild leaf mottling of infected plants, including weedy hosts (Koenig and Lesemann 1989).

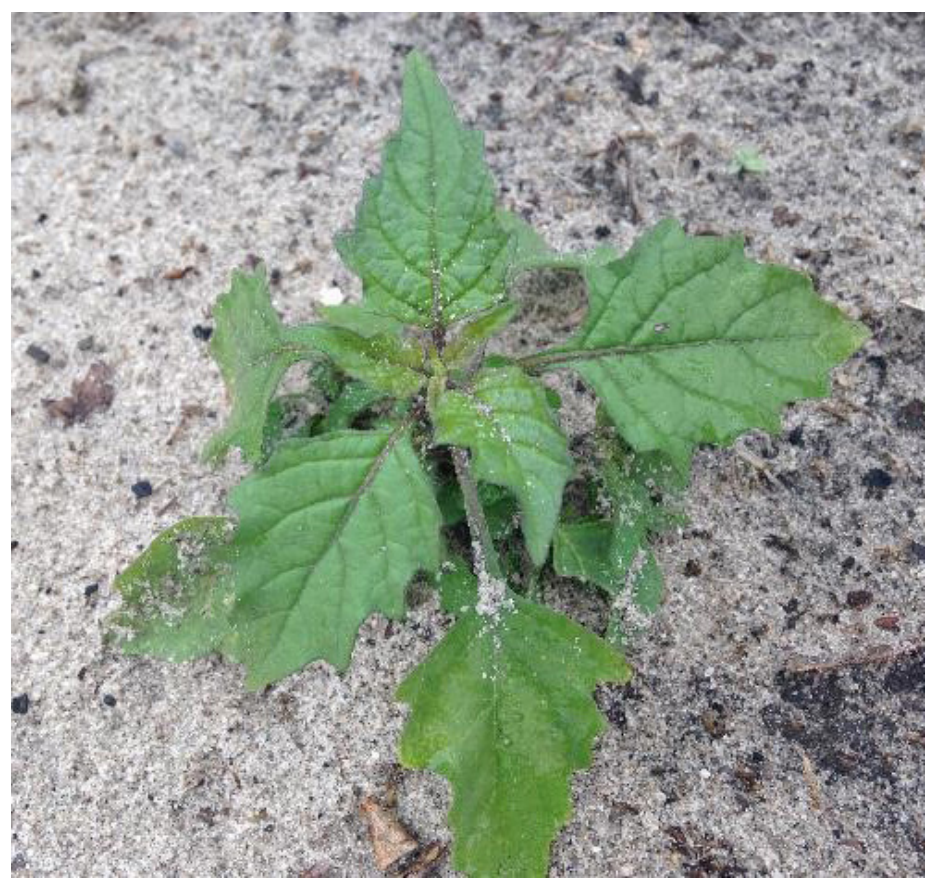

Figure 8. Jimsonweed, a member of the Solanaceae family. Credits: P. Dittmar, UF/IFAS 


\section{Selected References}

Adkins, S., S. E. Webb, C. A. Baker, and C. S. Kousik. 2008. Squash vein yellowing virus detection using nested polymerase chain reaction demonstrates that the cucurbit weed Momordica charantia is a reservoir host. Plant Disease 92: 1119-1123.

Aftab, M., and A. Freeman. 2013. Temperate pulse viruses: Beet western yellows virus (BWYV). Agriculture Victoria, Note AG1419. http://agriculture.vic.gov.au/agriculture/ pests-diseases-and-weeds/plant-diseases/grains-pulsesand-cereals/temperate-pulse-viruses-beet-western-yellowsvirus-bwyv (Accessed 10 September 2018).

Alemu, T., J. Hamacher, and H. W. Dehne. 2002. The role of some weeds as hosts of Capsicum viruses in the rift valley parts of Ethiopia. Meded Rijksuniv Gent Fak Landbouwkd Toegep Biologische Wetenschappen 67: 283-289.

Baker, C., S. Webb, and S. Adkins. 2008. Squash vein yellowing virus, causal agent of watermelon vine decline in Florida. Plant Pathology Circular No. 407. Florida Department of Agriculture and Consumer Services Division of Plant Industry. https://www.freshfromflorida.com/ content/download/11413/144774/pp407.pdf (Accessed 10 September 2018).

Dille, J. A., P. H. Sikkema, W. J. Everman, V. M. Davis, and I. C. Burke. 2016a. Perspectives on corn yield losses due to weeds in North America. Weed Science Society of America. http://wssa.net/wp-content/uploads/WSSA2015-Corn-Yield-Loss-poster-updated-calc.pdf (Accessed 10 September 2018).

Dille, J. A., P. H. Sikkema, W. J. Everman, V. M. Davis, and I. C. Burke. 2016b. Perspectives on soybean yield losses due to weeds in North America. Weed Science Society of America. Abstract available: https://www.cambridge.org/core/journals/weed-technology/article/div-classtitleperspectives-onpotential-soybean-yield-losses-from-weeds-in-north-americadiv/839B31C6771865071E6956BAEFC0F076 (Accessed 10 September 2018).

Dikova, B. 2006. Establishment of Tobacco rattle virus (TRV) in weeds and Cuscuta. Biotechnology and Biotechnological Equipment 20: 42-48.

El-Wakil, M. A., G. E. Holcomb, and T. Harger. 1985. Occurrence and identification of some weed diseases and their consideration for biological weed control. Proceedings of the VI International Symposium on Biological Control of Weeds pp. 613-616. https://www.ibiocontrol.org/
proceedings/volume.cfm?id=VI (Accessed 10 September 2018).

Gatton, H. A. 2015. Crop profile for sweet corn in Virginia. IPM Crop Profiles, Virginia Polytechnic Institute \& State University. https://ipmdata.ipmcenters.org/documents/ cropprofiles/VA_CP_SweetCorn_2015.pdf (Accessed 10 September 2018).

Goyal, G., K. G. Harsimran, and R. McSorley. 2012. Common weed hosts of insect-transmitted viruses of Florida vegetable crops. ENY-863. Gainesville: University of Florida Institute of Food and Agricultural Sciences. http://edis.ifas. ufl.edu/in931 (Accessed 10 September 2018).

Koenig, R., and D-E. Lesemann. 1989. Potato virus X. Description of Plant Viruses DPV 354, Association of Applied Biologists. http://www.dpvweb.net/dpv/showdpv. php?dpvno=354 (Accessed 10 September 2018).

Kucharek, T., and D. Purcifull. 2001. Aphid-transmitted viruses of cucurbits in Florida. Plant Pathology Department Circular 1184.

Papaix, J., J. J. Burdon, K. Zhan, and P. H. Thral. 2015. Crop pathogen emergence and evolution in agro-ecological landscapes. Evolutionary Applications 8: 385-402.

Rupe, J., and L. Sconyers. 2008. Soybean rust. The Plant Health Instructor. DOI: 10.1094/PHI-I-2008-0401-01. https://www.apsnet.org/edcenter/intropp/lessons/fungi/ Basidiomycetes/Pages/SoybeanRust.aspx (Accessed 10 September 2018).

Shrestha, D., H. J. McAuslane, S. T. Adkins, H. A. Smith, N. Dufault, and S. E. Webb. 2016. Transmission of Squash vein yellowing virus to and from cucurbit weeds and effects on sweetpotato whitefly (Hemiptera: Aleyrodidae) behavior. Environmental Entomology 45: 967-973. DOI: http://dx.doi. org/10.1093/ee/nvw086.

White, N. H. 1970. Weeds as reservoirs of plant diseases. Council of Australasian Weed Societies, Inc. http://caws. org.au/awc/1970/awc197011821.pdf (Accessed 10 September 2018).

Wisler, G. C., and R. F. Norris. 2005. Interactions between weeds and cultivated plants as related to management of plant pathogens. Weed Science 53: 914-917. 
Yandoc-Ables, C. B., E. N. Rosskopf, and R. Charudattan. 2006. Plant pathogens at work: Progress and possibilities for weed biocontrol, Part 1: Classical vs. bioherbicidal approach. American Phytopathological Society Features. http://www.apsnet.org/publications/apsnetfeatures/Pages/ WeedBiocontrolPart1.aspx (Accessed 10 September 2018).

Zitter, T. A., and R. Provvidenti. 1984. Virus diseases of leafy vegetables and celery. Cornell University Vegetable MD Online, Fact Sheet Page 737.00.

Zitter, T. A., and J. F. Murphy. 2009. Cucumber mosaic virus. The Plant Health Instructor. DOI: 10.1094/PHII-2009-0518-01 https://www.apsnet.org/edcenter/intropp/ lessons/viruses/Pages/Cucumbermosaic.aspx (Accessed 10 September 2018). 
Table 1. A chart listing the relationships between plant family, weed species, pathogen, and crops mentioned in the text of this publication.

\begin{tabular}{|c|c|c|c|c|}
\hline Plant Family & Weed & Pathogen & Crops affected & Reference \\
\hline Amaranthaceae & $\begin{array}{l}\text { Palmer amaranth, } \\
\text { (Amaranthus } \\
\text { palmeri), common } \\
\text { lambsquarters } \\
\text { (Chenopodium album) }\end{array}$ & Tobacco rattle virus (Tobravirus) & Beet, tobacco, potato & Dikova 2006, Goyal et al. 2012 \\
\hline Brassicaceae & $\begin{array}{l}\text { Wild radish } \\
\text { (Raphanus } \\
\text { raphanistrum) }\end{array}$ & $\begin{array}{l}\text { Beet western yellows virus } \\
\text { (Polerovirus) }\end{array}$ & $\begin{array}{l}\text { Broccoli, cauliflower, } \\
\text { radish, and turnip (also } \\
\text { beet, lettuce, spinach, } \\
\text { and pea) }\end{array}$ & Zitter and Provvidenti 1984 \\
\hline \multirow[t]{3}{*}{ Cucurbitaceae } & $\begin{array}{l}\text { Wild cucurbits } \\
\text { (Cucumis spp.) }\end{array}$ & $\begin{array}{l}\text { Cucumber mosaic virus } \\
\text { (Cucumovirus) }\end{array}$ & $\begin{array}{l}\text { Cantaloupe, cucumber, } \\
\text { pumpkin, and squash } \\
\text { (also bell pepper, celery, } \\
\text { spinach, tomato, and } \\
\text { watercress) }\end{array}$ & Goyal et al. 2012 \\
\hline & $\begin{array}{l}\text { Creeping cucumber } \\
\text { (Melothria pendula) }\end{array}$ & $\begin{array}{l}\text { Papaya ringspot virus type } \\
\text { W, Zucchini yellow mosaic } \\
\text { virus (both aphid-transmitted } \\
\text { Potyviruses) }\end{array}$ & $\begin{array}{l}\text { Cantaloupe, squash, } \\
\text { watermelon }\end{array}$ & Kucharek and Purcifull, 2001 \\
\hline & $\begin{array}{l}\text { Balsam apple or } \\
\text { balsam pear } \\
\text { (Momordica } \\
\text { charantia) }\end{array}$ & $\begin{array}{l}\text { Squash vein yellowing } \\
\text { virus (whitefly-transmitted } \\
\text { Ipomovirus) }\end{array}$ & Squash and watermelon & Adkins et al. 2008, Shrestha et al. 2016 \\
\hline Fabaceae & $\begin{array}{l}\text { Kudzu (Pueraria mont } \\
\text { ana var. lobata), } \\
\text { Florida beggarweed } \\
\text { (Desmodium } \\
\text { tortuosum), clover } \\
\text { (Trifolium spp.) }\end{array}$ & $\begin{array}{l}\text { Soybean rust, } \text { Phakopsora } \\
\text { pachyrhizi and } P \text {. } \\
\text { meibomiae (Basidiomycota: } \\
\text { Pucciniomycotina) }\end{array}$ & $\begin{array}{l}\text { Soybean, common bean, } \\
\text { garden and field peas }\end{array}$ & Rupe and Sconyers 2008 \\
\hline Poaceae & $\begin{array}{l}\text { Johnsongrass } \\
\text { (Sorghum halepense) }\end{array}$ & $\begin{array}{l}\text { Maize dwarf mosaic virus A } \\
\text { (aphid-transmitted Potyvirus) }\end{array}$ & Corn & Gatton 2015 \\
\hline Solanaceae & $\begin{array}{l}\text { Jimsonweed } \\
\text { (Datura stramonium) }\end{array}$ & $\begin{array}{l}\text { Tomato mosaic virus } \\
\text { (Tobamovirus) } \\
\text { Potato virus X (Potexvirus) }\end{array}$ & Pepper, tomato & Alemu et al. 2002 \\
\hline
\end{tabular}

